\title{
Microclimate and development of 'Conilon' coffee intercropped with rubber trees
}

\author{
Fábio Luiz Partelli(1), André Vasconcellos Araújo(1), Henrique Duarte Vieira(2), Jairo Rafael Machado Dias ${ }^{(3)}$, \\ Luis Fernando Tavares de Menezes ${ }^{(1)}$ and José Cochicho Ramalho ${ }^{(4)}$
}

\begin{abstract}
(1)Universidade Federal do Espírito Santo, Rodovia BR 101 Norte, Km 60, Bairro Litorâneo, CEP 29932-540 São Mateus, ES, Brazil. E-mail: partelli@yahoo.com.br, andre_vasconcellos@hotmail.com, Itmenezes@gmail.com (2)Universidade Estadual do Norte Fluminense Darcy Ribeiro, Laboratório de Fitotecnia, Avenida Alberto Lamego, oo 2.000, CEP 28013-602 Campos dos Goytacazes, RJ, Brazil. E-mail: henrique@uenf.br (3)Universidade Federal de Rondônia, Departamento de Agronomia, Avenida Norte Sul, no 7.300, Bairro Nova Morada, CEP 76940-000 Rolim de Moura, RO, Brazil. E-mail: jairorafaelmdias@hotmail.com ${ }^{(4)}$ Instituto de Investigação Científica Tropical, Centro de Ambiente, Agricultura e Desenvolvimento, Avenida República, Quinta do Marquês, 2784-505 Oeiras, Portugal. E-mail: cochichor@iict.pt
\end{abstract}

\begin{abstract}
The objective of this work was to evaluate the influence of intercropping 'Conilon' coffee (Coffea canephora) with rubber trees on coffee tree microclimate, nutrition, growth, and yield. Rubber trees were planted in two double rows $33 \mathrm{~m}$ apart, with $4 \times 2.3 \mathrm{~m}$ spacing between plants. Treatments consisted of the distances from the coffee plants to the rubber trees: 3, 6, 9, 12, and $15 \mathrm{~m}$. Measurements of atmospheric variables (temperature, irradiance, and relative humidity), leaf nutrient concentration, internode length of plagiotropic and orthotropic branches, individual leaf area, chlorophyll content, and yield were performed. Intercropping promotes changes in the microclimatic conditions of coffee plants close to rubber trees, with reduction of temperature and irradiance level and increase in air relative humidity. The proximity of the coffee tree to the rubber trees promotes the elongation of the plagiotropic and orthotropic branches and increases the individual leaf area; however, it does not affect leaf concentrations of $\mathrm{N}, \mathrm{K}, \mathrm{Mg}, \mathrm{Fe}, \mathrm{Zn}$, and $\mathrm{B}$ in 'Conilon' coffee and does not have a negative impact on yield.
\end{abstract}

Index terms: Coffea canephora, Hevea brasiliensis, irradiance, monoculture, shading.

\section{Microclima e desenvolvimento do café 'Conilon' consorciado com seringueira}

Resumo - O objetivo deste trabalho foi avaliar a influência do consórcio do cafeeiro 'Conilon' (Coffea canephora) com seringueira no microclima, na nutrição, no crescimento e na produtividade do cafeeiro. As seringueiras foram plantadas em duas fileiras duplas, distantes $33 \mathrm{~m}$, no espaçamento de $4 \times 2,3 \mathrm{~m}$ entre as plantas. Os tratamentos consistiram das distâncias dos cafeeiros em relação às seringueiras: $3,6,9,12 \mathrm{e}$ $15 \mathrm{~m}$. Foram realizadas medidas das variáveis atmosféricas (temperatura, irradiância e humidade relativa), da concentração foliar dos nutrientes, do comprimento dos entrenós de ramos plagiotrópicos e ortotrópicos, da área foliar individual, da concentração de clorofila e da produtividade. O consórcio promove mudanças nas condições microclimáticas dos cafeeiros próximos da seringueira, tendo ocorrido diminuição da temperatura e da irradiância e aumento da umidade relativa do ar. A proximidade do cafeiro em relação às seringueiras promove alongamento dos ramos plagiotrópicos e ortotrópicos e aumenta a área foliar individual; porém, não afeta as concentrações foliares de $\mathrm{N}, \mathrm{K}, \mathrm{Mg}, \mathrm{Fe}, \mathrm{Zn}$ e B em café 'Conilon' e não tem impacto negativo na produtividade.

Termos para indexação: Coffea canephora, Hevea brasiliensis, irradiância, monocultura, sombreamento.

\section{Introduction}

Coffee evolved in African forest understories and, therefore, has been traditionally considered a shade-requiring species. Even so, adequate management may allow its cultivation under full sun, frequently achieving higher yields than shaded coffee crops (DaMatta, 2004). In this way, it could be assumed that coffee tree has the necessary phenotypic plasticity to acclimate to contrasting light environments (Matos et al., 2009).

However, since excessive shading may lead to a decrease in coffee bean yield, the level of shading and the species that provide it are of utmost importance. 
The cultivation of coffee intercropped with other tree species has some advantages compared to the monocrop system, as it promotes yield stability by lowering strong variations in consecutive years, increases plant lifespan, and makes it easier to certify that the coffee is sustainable. Other advantages include: a decrease in the use of nitrogen fertilizers; an attenuation of the stress caused by temperature extremes, including frost; a reduction in transpiration flow, decreasing water use; and a greater carbon sequestration (Siles et al., 2010).

Coffee plants are able to acclimate to high levels of irradiance by triggering photoprotection and antioxidant mechanisms and by reinforcing photosynthetic machinery components, as long as the plant has an adequate supply of nitrogen (Ramalho et al., 1998). However, it is often reported that high irradiance hampers photosynthesis in coffee leaves, with higher net photosynthesis observed on cloudy days (Ronquim et al., 2006). In fact, the average yield of 12 year old agroforestry systems, which also provide environmental mitigation, may be $43 \%$ greater than that of full-sun crops, compensating for the higher cost of establishing the agroforestry system (Souza et al., 2012).

Coffee crops are often subjected to high temperatures in the summer, sometimes exceeding $38^{\circ} \mathrm{C}$ during the critical grain-filling stage (Partelli et al., 2010, 2013). These conditions, combined with the occurrence of strong winds and high evapotranspiration rates, cause environmental stress for the crop, requiring different techniques to mitigate these problems. Along with the improvement in water conditions, the obtained benefits result in an increase in productivity, a reduction in yield costs, and in a valuable addition to the coffee crops in some marginal regions (Lin, 2007). Therefore, the microclimate provided by trees in an agrosystem and its impact on coffee trees is important for this crop's management and viability.

The objective of this work was to evaluate the influence of intercropping 'Conilon' coffee with rubber trees on coffee tree microclimate, nutrition, growth, and yield.

\section{Materials and Methods}

The research was conducted between January 2012 and May 2014 on a rural property in the municipality of Jaguaré, in the state of Espírito
Santo, Brazil (18 $56^{\prime} \mathrm{S}, 39^{\circ} 58^{\prime} \mathrm{W}$, at $70 \mathrm{~m}$ altitude). The climate is Aw, warm tropical, according to Köppen. The experimental area was plane, with an average annual temperature of $23.3^{\circ} \mathrm{C}$, an average annual precipitation of $1,200-1,300 \mathrm{~mm}$, and a rainy period from October to January. The soil is classified as a Latossolo Vermelho-Amarelo (Typic Hapludox) with a loamy sand texture (Santos et al., 2013). The soil was sampled in January 2012 with the aid of a soil probe, below the coffee tree canopies, and had the following characteristics in the $0-20 \mathrm{~cm}$ layer: $\mathrm{pH}$ 6; $27 \mathrm{mg} \mathrm{dm}^{-3} \mathrm{P} ; 45 \mathrm{mg} \mathrm{dm}^{-3} \mathrm{~K} ; 7 \mathrm{mg} \mathrm{dm}^{-3} \mathrm{~S}$; $2 \mathrm{cmol}_{\mathrm{c}} \mathrm{dm}^{-3} \mathrm{Ca} ; 0.4 \mathrm{cmol}_{\mathrm{c}} \mathrm{dm}^{-3} \mathrm{Mg} ; 0 \mathrm{cmol}_{\mathrm{c}} \mathrm{dm}^{-3}$ $\mathrm{Al} ; 2 \mathrm{cmol}_{\mathrm{c}} \mathrm{dm}^{-3} \mathrm{H}+\mathrm{Al} ; 2 \mathrm{dag} \mathrm{kg}^{-1}$ organic matter; $87 \mathrm{mg} \mathrm{dm}{ }^{-3} \mathrm{Fe} ; 14 \mathrm{mg} \mathrm{dm}^{-3} \mathrm{Zn} ; 2 \mathrm{mg} \mathrm{dm}^{-3} \mathrm{Cu} ; 24 \mathrm{mg}$ $\mathrm{dm}^{-3} \mathrm{Mn} ; 0.38 \mathrm{mg} \mathrm{dm}^{-3} \mathrm{~B} ; 19 \mathrm{mg} \mathrm{dm}^{-3} \mathrm{Na} ; 4,6 \mathrm{cmol}_{\mathrm{c}}$ $\mathrm{dm}^{-3}$ effective cation exchange capacity; and base saturation index of $56.5 \%$. The analyses were performed in a laboratory using the method described by Silva (2009).

The experiment was performed in a 'Conilon' coffee (Verdebras G35) crop (Coffea canephora Pierre ex A. Froehner) in a $3 \times 1 \mathrm{~m}$ spacing (3.333 plants per hectare) intercropped with rubber trees [Hevea brasiliensis (Willd. ex A. Juss.) Müll. Arg.] planted along two double rows $33 \mathrm{~m}$ apart, with $4 \times 2.3 \mathrm{~m}$ spacing between plants (135 plants per hectare). The coffee trees were planted at the end of 2006, and the rubber trees at the end of 2007. Crop management included irrigation. Both rubber tree rows were oriented $65^{\circ}$ Northwest. By the time of the experiment (2012), the rubber trees had a diameter at breast height $(\mathrm{DBH})$ of $45 \mathrm{~cm}$, a height of $10 \mathrm{~m}$, and a canopy diameter of $7 \mathrm{~m}$. The rows were $100 \mathrm{~m}$ long and had windbreaks composed of 35 year old rubber trees with a height of $17 \mathrm{~m}$, a DBH of $105 \mathrm{~cm}$, a canopy diameter of $14 \mathrm{~m}$, and a $3 \times 7 \mathrm{~m}$ spacing at the front and back ends.

Atmospheric variables (irradiance, temperature, and air relative humidity) were assessed considering five treatments, according to the distances from the rubber tree rows: T1, $3 \mathrm{~m}$; T2, $6 \mathrm{~m}$; T3, $9 \mathrm{~m}$; T4, $12 \mathrm{~m}$; and T5, $15 \mathrm{~m}$, on both the north and south sides of the coffee plant rows for a better microclimate characterization. Microclimatic monitoring and characterization were performed in two seasons of the year, with data collection on January 27 and 28 (summer) and on September 12 and 13 (winter) of 2012, between 06:00 and 19:00 hours (local time). 
During this time, the apparent movement of the sun was close to $1^{\circ}$ North in summer and to $21^{\circ}$ North in winter. The measurements included irradiance, temperature, and air relative humidity and were performed using HOBO U12 external data logger devices (Onset HOBO Data Loggers, Bourne, MA, USA), placed at a $3 \mathrm{~m}$ height above the coffee tree rows. The instruments were placed in the central part of the crop, at $45 \mathrm{~m}$ from the first coffee tree, to minimize external influences, with a $5 \mathrm{~m}$ spacing between data loggers. Three data loggers were placed in each row, resulting in three replicates, and were programmed to record data every $10 \mathrm{~min}$.

The growth characteristics of the coffee trees in the crop were assessed simultaneously with the microclimate measurements. The number of nodes was quantified, and the lengths of orthotropic branches, of plagiotropic branches with fruits, and of plagiotropic branches without fruits were measured. A total of 20 plants were assessed for each treatment - ten plants on the north side and ten on the south side of the coffee tree rows. The average internode length (etiolation) was obtained by dividing branch length by the number of nodes. For the branches with fruits (old branches), the distance between the nodes with coffee fruits and the branch type without fruits was also measured. The measurement of branches without fruits (young branches) consisted of the entire branch, and the orthotropic branch was measured from the youngest branch without coffee fruits to the tip of the orthotropic branch.

The coffee bean yield of three years $(2012,2013$, and 2014) was evaluated in order to overcome the effect of yield variation between consecutive years. Coffee seeds were collected manually on May of 2012, 2013 , and 2014 , when approximately $80 \%$ of the fruits were ripe. Three plants were sampled in each of the four plots, with a total of four replicates per treatment. The average coffee seed yield was quantified in liter per plant and extrapolated to $\mathrm{kg} \mathrm{ha}^{-1}$. The average ratio obtained for this crop, of $5.33 \mathrm{~L}$ of mature fruit per kilogram of processed coffee seed, was used.

For both seasons, sampling also included an estimation of the amounts of chlorophyll a and $b$, as well as of the total chlorophyll concentration of the leaves in the plant's mid-upper third, with 20 leaves per treatment. The third and fourth pairs of leaves were sampled with an electronic chlorophyll meter, model
CFL 1030 (Falker Automação Agrícola Ltda., Porto Alegre, RS, Brazil). Sixty leaves per treatment were also collected for nutrient analysis and measurement of individual leaf area. Leaf area was estimated according to Partelli et al. (2006). Leaf nutrient analysis was performed in triplicate only in summer.

The hypothesis of equality of the sampled variables between the treatments was tested using analysis of variance. Tukey's test was used for mean comparison at a $95 \%$ confidence level. Descriptive statistics were also used for microclimate data, including irradiance, temperature, and air relative humidity.

\section{Results and Discussion}

The level of irradiance was linked to the distance of the coffee rows to the rubber trees, with lower irradiance values in the coffee plants closer to the rubber tree rows (Figure 1). Also, those levels changed throughout the day, with the season and with the direction of shading (north or south). Regarding the time of year, irradiance at the leaf level was higher on the north side in summer, especially in the morning. Irradiance values also varied during the day. For instance, in summer, an average cumulative daily difference of $729 \mu \mathrm{mol} \mathrm{m} \mathrm{m}^{-2} \mathrm{~s}^{-1}$ was found between treatments T1 $(3 \mathrm{~m})$ and T5 $(15 \mathrm{~m})$, with the highest irradiances registered in the morning on the north side. In winter, the irradiation variation pattern was similar for the coffee trees at higher distances from the rubber trees, but with clear effects for the T1 $(3 \mathrm{~m})$ to T3 $(9 \mathrm{~m})$ treatments. Actually, smaller irradiance values were measured close to the rubber trees $(3 \mathrm{~m})$ compared to those observed at $15 \mathrm{~m}$, on the south side in the morning and on the north side in the afternoon. Also in winter, on the northern side, the irradiance values were similar up to $12: 00 \mathrm{~h}$, with no influence of rubber trees. Despite that, differences were observed in afternoon irradiance at leaf level, explaining why $\mathrm{T} 5$ had an average cumulative daily value $615 \mu \mathrm{mol} \mathrm{m} \mathrm{m}^{-2} \mathrm{~s}^{-1}$ higher than T1. However, on the southern side during winter, the cumulative daily value was $820 \mu \mathrm{mol} \mathrm{m} \mathrm{m}^{-2} \mathrm{~s}^{-1}$ higher in T5 when compared to $\mathrm{T} 1$; but this difference arises mostly from the morning sun exposure, when $\mathrm{T} 1$ to $\mathrm{T} 3$ received much lower irradiance, as there was little difference in irradiance after 15:00 h.

In coffee crops associated with other trees, coffee closer to these trees receives a lower amount of 
irradiance, since a large part of the incident light is captured by the tree canopies. This leads to changes in the microclimate near the trees, with a lower temperature and a higher relative air humidity (Pezzopane et al., 2011). In studies with an interception of 40 to $50 \%$ of irradiation, the coffee plant growth, as well as the coffee bean maturation, yield, and size were not altered (Pezzopane et al., 2011). Still, in agroforestry systems, the species $C$. arabica appears to experience limited stomatal conductance and availability of light for leaf photosynthesis under shading levels higher than $45 \%$ (Franck \& Vaast, 2009). However, coffee crops associated with coconut tree (Cocos nucifera L.), macadamia nut (Macadamia integrifolia Maiden \& Betche), banana tree (Musa sp.), and Inga densiflora Benth. underwent decreases of up to $80 \%$ in the total


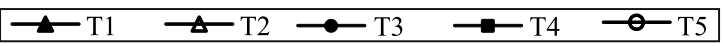

Figure 1. Daily irradiance values in 'Conilon' coffee (Coffea canephora) intercropped with rubber trees (Hevea brasiliensis) in summer on the northern (A) and southern (B) sides of the coffee tree rows and in winter on the northern (C) and southern (D) sides. T1, coffee row at $3 \mathrm{~m}$; T2, coffee row at $6 \mathrm{~m}$; T3, coffee row at $9 \mathrm{~m}$; T4, coffee row at $12 \mathrm{~m}$; and T5, coffee row at $15 \mathrm{~m}$ from the rubber trees. Each value represents the mean $(\mathrm{n}=3)$. 
amount of solar radiation at the coffee plant level, with an attenuation of extreme temperature values (Siles et al., 2010).

The highest temperature values were recorded in summer for the T5 treatment, whereas the lowest values were observed at $\mathrm{T} 1$ and $\mathrm{T} 2$, showing a decrease in air temperature at the level of coffee plants due to the presence of rubber trees (Figure 2). In fact, maximal temperature values of $38.3^{\circ} \mathrm{C}$ $(11: 30 \mathrm{~h})$ and $38.4^{\circ} \mathrm{C}(14: 00 \mathrm{~h})$, respectively, for the northern and southern sides, were found in T5. By the same time, the temperatures at $\mathrm{T} 1$ were 32.8 and $32.9^{\circ} \mathrm{C}$ on the same order, showing differences of $5.5^{\circ} \mathrm{C}$ on both sides in comparison to T5. In winter, the highest temperatures were recorded at $13: 10 \mathrm{~h}$ on the northern side $\left(37^{\circ} \mathrm{C}\right)$ and at $14: 40 \mathrm{~h}$ on the southern side $\left(37.4^{\circ} \mathrm{C}\right)$, both in T5. Conversely, the lowest temperatures that occurred at the same time were observed at $\mathrm{T} 1$, with 32.7 and $31.2^{\circ} \mathrm{C}$ on the
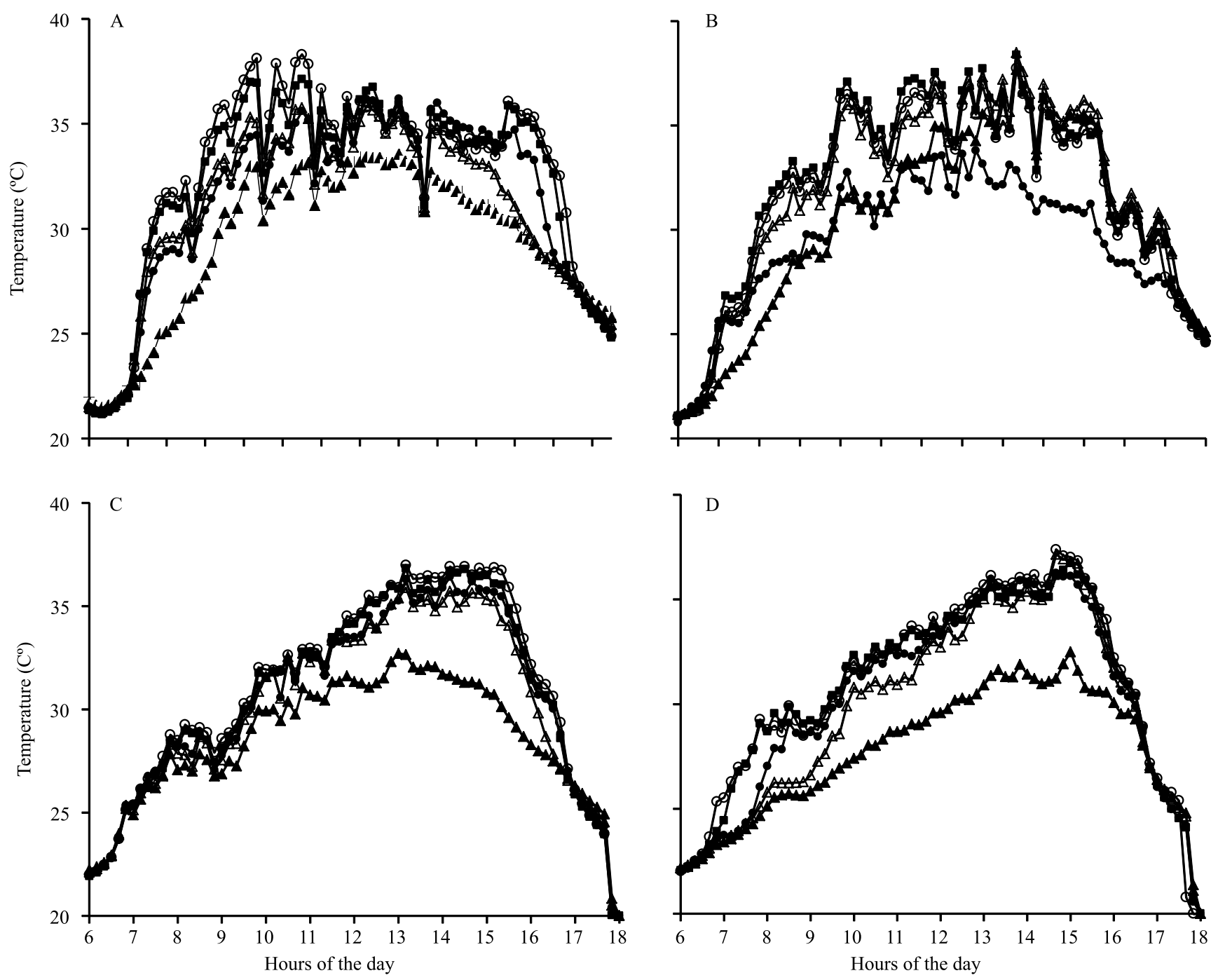

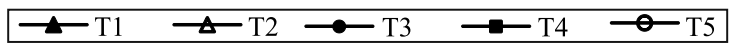

Figure 2. Daily mean temperature values in 'Conilon' coffee (Coffea canephora) intercropped with rubber trees (Hevea brasiliensis) in summer on the northern (A) and southern (B) sides of the coffee tree rows and in winter on the northern (C) and southern (D) sides. T1, coffee row at $3 \mathrm{~m}$; T2, coffee row at $6 \mathrm{~m}$; T3, coffee row at $9 \mathrm{~m}$; T4, coffee row at $12 \mathrm{~m}$; and T5, coffee row at $15 \mathrm{~m}$ from the rubber trees. Each value represents the mean $(\mathrm{n}=3)$. 
same order, and, therefore, with differences of 4.3 and $6.2^{\circ} \mathrm{C}$, respectively.

The reduction of maximum temperatures in full exposed leaves found in the present study was within the range reported by other authors, between $2.2^{\circ} \mathrm{C}$ in systems associated with macadamia nut (Pezzopane et al., 2010) and $10^{\circ} \mathrm{C}$ in those with pigeon pea [Cajanus cajan (L.) Millsp.] (Morais et al., 2003).

These reductions were mostly observed in the warmer months, during spring and summer, concomitantly to the critical phenological stages of flowering and fruiting and the greatest vegetative growth (Partelli et al., 2010, 2013). It is known that high temperature combined with high irradiation may hamper several leaf metabolic processes and increase the yield of highly reactive molecules of chlorophyll and oxygen, resulting in leaf damage (Ramalho et al., 1998; DaMatta \& Ramalho, 2006). In spite of this, photosynthetic tolerance in coffee plants was observed up to $33-35^{\circ} \mathrm{C}$, provided that the temperature increase was imposed gradually, allowing the plant to express acclimation features. In some cases, C. arabica plants might exhibit $\mathrm{P}_{\mathrm{n}}$ increases up to $35^{\circ} \mathrm{C}$, whereas, in others, C. arabica and C. canephora maintained the photosynthetic capacity $\left(\mathrm{A}_{\max }\right)$ up to $37^{\circ} \mathrm{C}$ (DaMatta \& Ramalho, 2006). These findings agree with the high coffee productivity found in tropical environments, where leaf temperature is often above $30^{\circ} \mathrm{C}$, particularly under full-sun crop management (DaMatta \& Ramalho, 2006).

Air relative humidity $(\mathrm{RH})$ patterns were almost opposite to those observed for irradiance and air temperature. RH in summer on the northern side showed the highest and lowest values in $\mathrm{T} 1$ and $\mathrm{T} 5$, respectively, for most of the hours of the day (Figure 3). Maximal difference was observed at 8:00 $\mathrm{h}(88.7 \%$ at $\mathrm{T} 1$ and $60.9 \%$ at $\mathrm{T} 5$ ), and the diurnal average difference reached $9.3 \%$. On the southern side, the highest difference was observed at 8:00 h $(84.2 \%$ at $\mathrm{T} 1$ and $65.8 \%$ at $\mathrm{T} 5$ ), although the diurnal average difference was only $4.7 \%$. Similar trends were observed in winter, with a diurnal average difference of $7 \%$ on the northern side and of $9.3 \%$ on the southern side between the higher (T5) and lower (T1) distances from the coffee plants to the rubber trees. These values are close to the average 5\% increase in atmospheric humidity reported for coffee crop intercropped with green-dwarf coconut trees (Pezzopane et al., 2011). Furthermore, decreased temperature, allied to the maintenance of higher $\mathrm{RH}$ and lower wind speed, has the effect of reducing the water vapor deficit between leaf and atmosphere, decreasing the plant's water loss through transpiration (DaMatta, 2004).

All branch types, in both seasons, showed significant increases in internode length in response to shading in $\mathrm{T} 1$ and T2 (Table 1), as also verified by Ricci et al. (2006) for coffee plants. This process, known as etiolation, is related not only to the amount but also to the quality of light. In fact, after passing through the leaves from the canopies, the spectral distribution of solar radiation changed for the plants below, having an increased proportion of far-red relative to red wavelengths. This promotes the transformation of far-red phytochrome $\left(\mathrm{P}_{\mathrm{fr}}\right)$ into red phytochrome $\left(\mathrm{P}_{\mathrm{r}}\right)$, reducing the ratio between $\mathrm{P}_{\text {fr }}$ and total phytochrome $\left(\mathrm{P}_{\text {total }}\right)$ (Morgan \& Smith, 1979).

Shading also caused a strong increase in individual leaf area, with maximum differences of $105 \%$ in summer and of $216 \%$ in winter between $\mathrm{T} 1$ and $\mathrm{T} 5$ (Table 1). These results are in accordance with Ricci et al. (2006), who observed increased leaf area in shaded $C$. arabica and C. canephora plants, when compared to full-sun exposed crops. Moreover, greater height growth, a smaller number of plagiotropic branches, and larger leaves were observed in shaded coffee (Morais et al., 2003).

The amounts of chlorophyll a during both seasons, of chlorophyll b, and of total chlorophyll in summer did not differ between treatments (Table 1). However, increases in chlorophyll $b$ and total chlorophyll were found in winter, for coffee trees at a greater distance from the rubber trees. This was also reported for chlorophyll b by Gonçalves et al. (2007) for less shaded leaves, which would be linked to the development of thicker leaves, if the pigment content is expressed in area bases (Senevirathna et al., 2003). Therefore, leaves that develop in shaded environments usually have a larger amount of total chlorophyll per unit mass to enhance their light absorption capacity (Feng et al., 2004). Additionally, plants with phenotypic plasticity, as appears to be the case of coffee plants, exhibit an increase in the amount of chlorophyll and a decrease in ribulose 1,5 bisphosphate carboxylase/ oxygenase (Rubisco) in environments with a low amount of available radiation (Morais et al., 2004).

Pesq. agropec. bras., Brasília, v.49, n.11, p.872-881, nov. 2014 DOI: 10.1590/S0100-204X2014001100006 
The average yield of the three years $(2012,2013$, and 2014), higher than worldwide average values, was similar between the five groups of plants (Table 1), agreeing with the results of Ricci et al. (2006). At this point, it must be highlighted that rubber tree products provide a supplementary source of economic income.

Leaf concentrations of the macronutrients $\mathrm{N}$, $\mathrm{K}$ and $\mathrm{Mg}$, and of the micronutrients $\mathrm{Fe}, \mathrm{Zn}$ and B were similar amongst distances to the rubber
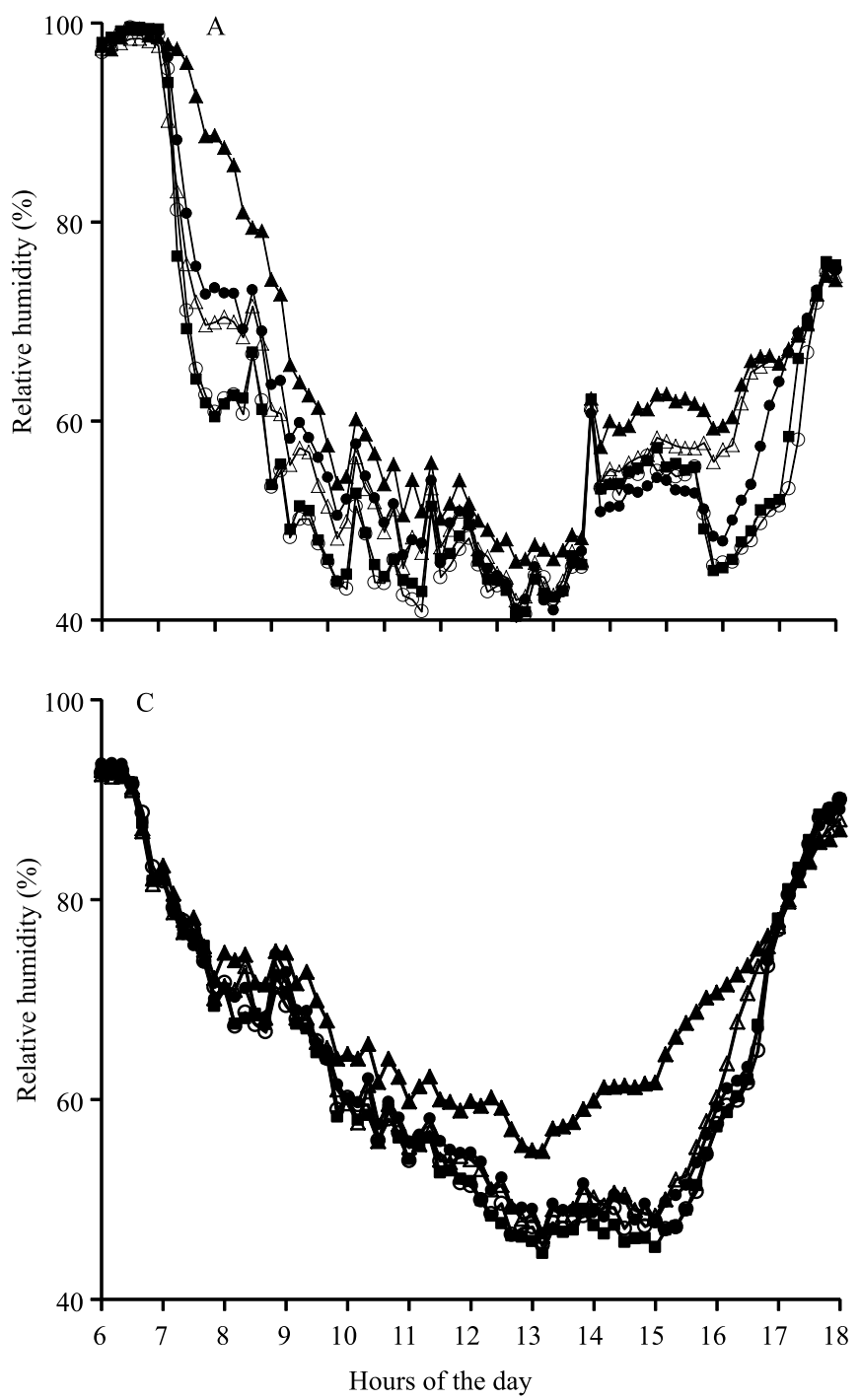

trees (Table 2). Therefore, shading did not affect the availability of these nutrients to coffee plants. Similar findings have been reported for $\mathrm{K}$ and $\mathrm{Mg}$ in shaded coffee systems, but with higher $\mathrm{N}$ concentrations (Ricci et al., 2006). The obtained values for leaf macro- and micronutrients can be considered close to adequate in $C$. arabica and $C$. canephora (Bragança et al., 2007, 2008; Ramalho et al., 2013; Martins et al., 2014), although the
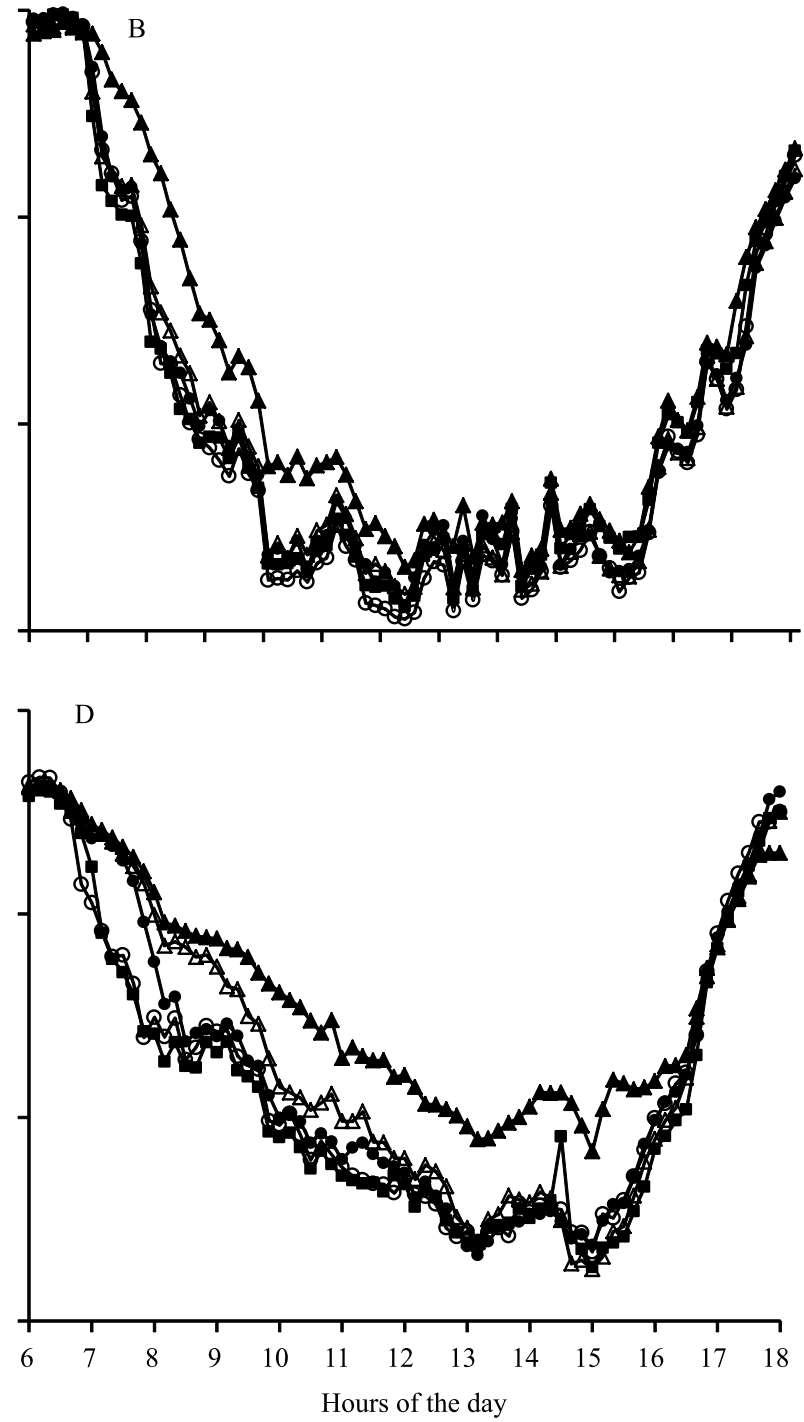

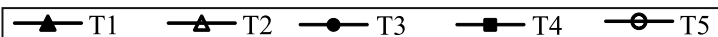

Figure 3. Daily mean relative humidity values in 'Conilon' coffee (Coffea canephora) intercropped with rubber trees (Hevea brasiliensis) in summer on the northern (A) and southern (B) sides of the coffee tree rows and in winter on the northern (C) and southern (D) sides. T1, coffee row at $3 \mathrm{~m}$; T2, coffee row at $6 \mathrm{~m}$; T3, coffee row at $9 \mathrm{~m}$; T4, coffee row at $12 \mathrm{~m}$; and T5, coffee row at $15 \mathrm{~m}$ from the rubber trees. Each value represents the mean $(\mathrm{n}=3)$. 
levels of $\mathrm{N}, \mathrm{Mg}, \mathrm{S}, \mathrm{Fe}$, and $\mathrm{Cu}$ might be considered somewhat below the one considered optimum for C. canephora 'Conilon' (Bragança et al., 2007, 2008). Higher concentrations of $\mathrm{Fe}$ and $\mathrm{B}$ have also been found in coffee monocultures compared to agroforestry systems (Campanha et al., 2007).

$\mathrm{P}$ concentration was lower in the row closest to the rubber trees (Table 2), contrary to what has been observed in other studies, which did not detect a significant difference in the amount of $\mathrm{P}$ between the shaded system and the monoculture (Ricci et al., 2006; Campanha et al., 2007). The amount of S was lowest in T1, but only when compared to T4. However, $\mathrm{Ca}$ and $\mathrm{Mn}$ contents were higher in $\mathrm{T} 1$, especially with regard to the latter element, which exhibited a 59\% increase when compared to $\mathrm{T} 5$. Calcium is indispensable for the integrity of the cell plasma membrane and also plays an important role in cell signaling. Its increase in shaded systems has also been observed by Campanha et al. (2007), in comparison to monoculture systems. Concerning $\mathrm{Mn}$ contents, a higher leaf content of this mineral was obtained in the plants closer to the rubber trees (T1), that is, in those plants that received lower irradiance levels, diverging from reports of a higher Mn value under conditions of higher irradiance (Campanha et al., 2007; Gonçalves et al., 2007). In addition, Mn has important biochemical roles, since it is an integral part of the antioxidant enzyme Mn-SOD and has a close association to the oxygen evolving complex in photosystem II (OEC in PS II), in which it is required for water splitting and $\mathrm{O}_{2}$ evolution. $\mathrm{Mn}$ is also an activator of several enzymes, such as peroxidases and enzymes from $\mathrm{N}$ metabolism, decarboxylases and dehydrogenases in the Krebs cycle (Ramalho et al., 2013, 2014). Therefore, its increase above adequate levels (Bragança et al., 2007) in the T1 shaded plants may play an important metabolic role.

Table 1. Internode length of the plagiotropic and orthotropic branches, individual leaf area (ILA), average amount of chlorophyll (relative index of chlorophyll) in the leaves, and average yield (2012, 2013, and 2014) of 'Conilon' coffee (Coffea canephora) intercropped with rubber trees (Hevea brasiliensis) in the summer (S) and winter (W) of 2012 ${ }^{(1)}$.

\begin{tabular}{|c|c|c|c|c|c|c|c|c|c|c|c|c|c|c|c|}
\hline \multirow[t]{2}{*}{ Treatment } & \multicolumn{6}{|c|}{ Growth of plagiotropic branches $(\mathrm{cm})$} & \multicolumn{2}{|c|}{ ILA $\left(\mathrm{cm}^{2}\right)$} & \multicolumn{2}{|c|}{ Chlorophyll a } & \multicolumn{2}{|c|}{ Chlorophyll b } & \multicolumn{2}{|c|}{ Total chlorophyll } & \multirow{2}{*}{$\begin{array}{l}1 \text { Yield } \\
\left(\mathrm{kg} \mathrm{ha}^{-1}\right)\end{array}$} \\
\hline & PBWF (S) & ГРPB (S) & YPB (S) & $\mathrm{OB}(\mathrm{S})$ & YPB (W) & $\mathrm{OB}(\mathrm{W})$ & $\mathrm{S}$ & W & $\mathrm{S}$ & W & $\mathrm{S}$ & W & $\mathrm{S}$ & W & \\
\hline $\mathrm{T} 1$ & $5.1 \mathrm{ab}$ & $3.6 \mathrm{a}$ & $5.7 \mathrm{a}$ & $4.1 \mathrm{a}$ & $4.1 \mathrm{a}$ & $2.5 \mathrm{a}$ & $93.2 \mathrm{a}$ & $109.1 \mathrm{a}$ & $41.1 \mathrm{a}$ & $39.6 \mathrm{a}$ & $18.3 \mathrm{a}$ & $17.0 \mathrm{c}$ & $59.1 \mathrm{a}$ & $56.5 \mathrm{c}$ & $4,248 \mathrm{a}$ \\
\hline $\mathrm{T} 2$ & $5.2 \mathrm{a}$ & $3.6 \mathrm{a}$ & $5.1 \mathrm{~b}$ & $3.7 \mathrm{a}$ & $4.1 \mathrm{a}$ & $2.4 \mathrm{a}$ & $84.6 \mathrm{a}$ & $71.0 \mathrm{~b}$ & $42.6 \mathrm{a}$ & $41.4 \mathrm{a}$ & $22.9 \mathrm{a}$ & $25.5 \mathrm{ab}$ & $65.5 \mathrm{a}$ & $66.9 \mathrm{ab}$ & $4,386 a$ \\
\hline $\mathrm{T} 3$ & $4.4 \mathrm{ab}$ & $3.1 \mathrm{ab}$ & $4.7 \mathrm{bc}$ & $3.2 \mathrm{~b}$ & $3.8 \mathrm{ab}$ & $2.3 \mathrm{ab}$ & $72.1 b$ & $62.0 \mathrm{c}$ & $43.0 \mathrm{a}$ & $38.6 \mathrm{a}$ & $20.7 \mathrm{a}$ & $19.9 b c$ & $63.7 \mathrm{a}$ & $66.9 \mathrm{ab}$ & $4,392 \mathrm{a}$ \\
\hline $\mathrm{T} 4$ & $4.8 \mathrm{ab}$ & $3.0 \mathrm{~b}$ & $4.5 \mathrm{c}$ & $2.8 \mathrm{~b}$ & $3.5 b$ & $2.1 b$ & $56.5 \mathrm{c}$ & $50.8 \mathrm{~d}$ & $42.6 \mathrm{a}$ & $41.2 \mathrm{a}$ & $18.1 \mathrm{a}$ & $23.7 \mathrm{abc}$ & $60.7 \mathrm{a}$ & $58.5 \mathrm{bc}$ & $4,206 a$ \\
\hline $\mathrm{T} 5$ & $4.3 b$ & $2.9 \mathrm{~b}$ & $4.4 \mathrm{c}$ & $2.9 \mathrm{~b}$ & $3.5 \mathrm{~b}$ & $2.0 \mathrm{~b}$ & $45.4 d$ & $34.6 \mathrm{e}$ & $42.0 \mathrm{a}$ & $40.6 \mathrm{a}$ & $19.8 \mathrm{a}$ & $27.5 \mathrm{a}$ & $61.7 \mathrm{a}$ & $68.1 \mathrm{a}$ & $4,332 \mathrm{a}$ \\
\hline $\mathrm{CV}(\%)$ & 32.2 & 27.9 & 17.7 & 23.6 & 19.2 & 22.8 & 22.4 & 23.5 & 5.5 & 9.4 & 52.7 & 36.1 & 20.0 & 17.3 & 16.6 \\
\hline
\end{tabular}

${ }^{(1)}$ Means followed by equal letters, in the columns, do not differ by Tukey's test, at 5\% probability. T1, coffee row at 3 m; T2, coffee row at 6 m; T3, coffee row at $9 \mathrm{~m}$; T4, coffee row at $12 \mathrm{~m}$; and T5, coffee row at $15 \mathrm{~m}$ from the rubber trees. PBWF, plagiotropic branches with fruits; TPPB, tip of the productive plagiotropic branches; YPB, young plagiotropic branches; and $\mathrm{OB}$, orthotropic branches.

Table 2. Mean concentrations of N, $\mathrm{P}, \mathrm{K}, \mathrm{Ca}, \mathrm{Mg}$, and $\mathrm{S}\left(\mathrm{g} \mathrm{kg}^{-1}\right)$ and of Fe, $\mathrm{Zn}, \mathrm{Cu}, \mathrm{Mn}$, and B (mg kg-1) in leaves of 'Conilon' coffee (Coffea canephora) intercropped with rubber trees (Hevea brasiliensis) in the summer of $2012^{(1)}$.

\begin{tabular}{|c|c|c|c|c|c|c|c|c|c|c|c|}
\hline \multirow[t]{2}{*}{ Treatment } & \multicolumn{11}{|c|}{ Mineral leaf concentration } \\
\hline & $\mathrm{N}$ & $P$ & $\mathrm{~K}$ & $\mathrm{Ca}$ & $\mathrm{Mg}$ & $\mathrm{S}$ & $\mathrm{Fe}$ & $\mathrm{Zn}$ & $\mathrm{Cu}$ & $\mathrm{Mn}$ & $\mathrm{B}$ \\
\hline $\mathrm{T} 1$ & $24.3 \mathrm{a}$ & $1.3 b$ & $17.9 \mathrm{a}$ & $17.3 \mathrm{a}$ & $2.5 \mathrm{a}$ & $1.3 b$ & $59.7 \mathrm{a}$ & $9.7 \mathrm{a}$ & $8.0 \mathrm{a}$ & $97.7 \mathrm{a}$ & $63.5 \mathrm{a}$ \\
\hline $\mathrm{T} 2$ & $24.7 \mathrm{a}$ & $1.5 \mathrm{a}$ & $20.6 \mathrm{a}$ & $14.5 b$ & $2.4 \mathrm{a}$ & $1.4 \mathrm{ab}$ & $54.5 \mathrm{a}$ & $9.0 \mathrm{a}$ & $6.0 \mathrm{~b}$ & $73.5 \mathrm{ab}$ & $54.0 \mathrm{a}$ \\
\hline $\mathrm{T} 3$ & $24.2 \mathrm{a}$ & $1.4 \mathrm{a}$ & $19.0 \mathrm{a}$ & $14.0 \mathrm{~b}$ & $2.1 \mathrm{a}$ & $1.4 \mathrm{ab}$ & $61.7 \mathrm{a}$ & $10.0 \mathrm{a}$ & $7.2 \mathrm{ab}$ & $74.2 \mathrm{ab}$ & $51.0 \mathrm{a}$ \\
\hline $\mathrm{T} 4$ & $23.8 \mathrm{a}$ & $1.5 \mathrm{a}$ & $18.4 \mathrm{a}$ & $14.2 \mathrm{~b}$ & $2.3 \mathrm{a}$ & $1.6 \mathrm{a}$ & $65.7 \mathrm{a}$ & $9.0 \mathrm{a}$ & $7.2 \mathrm{ab}$ & $65.0 \mathrm{~b}$ & $58.5 \mathrm{a}$ \\
\hline T5 & $24.6 \mathrm{a}$ & $1.4 \mathrm{a}$ & $18.7 \mathrm{a}$ & $14.4 \mathrm{~b}$ & $2.2 \mathrm{a}$ & $1.4 \mathrm{ab}$ & $61.5 \mathrm{a}$ & $8.2 \mathrm{a}$ & $8.2 \mathrm{a}$ & $61.5 \mathrm{~b}$ & $57.0 \mathrm{a}$ \\
\hline $\mathrm{CV}(\%)$ & 4.6 & 4.6 & 7.2 & 7.2 & 11.5 & 9.4 & 10.4 & 12.4 & 10.1 & 18.8 & 10.1 \\
\hline
\end{tabular}

${ }^{(1)}$ Means followed by equal letters, in the columns, do not differ by Tukey's test, at 5\% probability. T1, coffee row at 3 m; T2, coffee row at 6 m; T3, coffee row at $9 \mathrm{~m}$; T4, coffee row at $12 \mathrm{~m}$; and T5, coffee row at $15 \mathrm{~m}$ from the rubber trees. 


\section{Conclusions}

1. The intercropping of 'Conilon' coffee (Coffea canephora) with rubber trees (Hevea brasiliensis) promotes changes in microclimatic conditions, lowering the irradiance level, attenuating the temperature range, and increasing air relative humidity.

2. The proximity to the rubber trees promotes the elongation of the plagiotropic and orthotropic branches, increases the individual leaf area, and does not affect leaf concentrations of $\mathrm{N}, \mathrm{K}, \mathrm{Mg}, \mathrm{Fe}, \mathrm{Zn}$, and $\mathrm{B}$ in 'Conilon' coffee trees, having no negative impact on yield.

\section{Acknowledgements}

To Coordenação de Aperfeiçoamento de Pessoal de Nível Superior (Capes) and to Universidade Federal do Espírito Santo (Ufes), for partial financial support; and to Mr. Fabrício Felisberto Fiorot, for allowing the use of the experimental area.

\section{References}

BRAGANÇA, S.M.; PRIETO MARTINEZ, H.E.; LEITE, H.G.; SANTOS, L.P.; SEDIYAMA, C.S.; ALVAREZ V., V.H.; LANI, J.A. Accumulation of macronutrients for the conilon coffee tree. Journal of Plant Nutrition, v.31, p.103-120, 2008. DOI: 10.1080/01904160701741990.

BRAGANÇA, S.M.; PRIETO MARTINEZ, H.E.; LEITE, H.G.; SANTOS, L.P.; SEDIYAMA, C.S.; ALVAREZ V., V.H.; LANI, J.A. Acúmulo de B, Cu, Fe, Mn e Zn pelo cafeeiro conilon. Revista Ceres, v.54, p.398-404, 2007

CAMPANHA, M.M.; SANTOS, R.H.S.; FREITAS, G.B. de; MARTINEZ, H.E.P.; JARAMILLO-BOTERO, C.; GARCIA, S.L. Análise comparativa das características da serrapilheira e do solo em cafezais (Coffea arabica L.) cultivados em sistema agroflorestal e em monocultura, na Zona da Mata MG. Revista Árvore, v.31, p.805-812, 2007. DOI: 10.1590/S0100-67622007000500004.

DAMATTA, F.M. Ecophysiological constraints on the production of shaded and unshaded coffee: a review. Field Crops Research, v.86, p.99-114, 2004. DOI: 10.1016/j.fcr.2003.09.001.

DAMATTA, F.M.; RAMALHO, J.D.C. Impacts of drought and temperature stress on coffee physiology and production: a review. Brazilian Journal of Plant Physiology, v.18, p.55-81, 2006. DOI: 10.1590/S1677-04202006000100006.

FENG, Y.L.; CAO, K.F.; ZHANG, J.L. Photosynthetic characteristics, dark respiration, and leaf mass per unit area in seedlings of four tropical tree species grown under three irradiances. Photosynthetica, v.42, p.431-437, 2004. DOI: 10.1023/B:PHOT.0000046163.83729.e5.
FRANCK, N.; VAAST, P. Limitation of coffee leaf photosynthesis by stomatal conductance and light availability under different shade levels. Trees, v.23, p.761-769, 2009. DOI: 10.1007/ s00468-009-0318-z.

GONÇALVES, G.C.; GALLO, L.A.; FAVARIM, J.L. Assimilação do carbono por plantas de cafeeiro (Coffea arabica L. var. Obatã) crescendo a pleno sol e com sombreamento parcial. Revista de Agricultura, v.82, p.35-46, 2007.

LIN, B.B. Agroforestry management as an adaptive strategy against potential microclimate extremes in coffee agriculture. Agricultural and Forest Meteorology, v.144, p.85-94, 2007. DOI: 10.1016/j.agrformet.2006.12.009.

MARTINS, L.D.; TOMAZ, M.A.; LIDON, F.C.; DAMATTA, F.M.; RAMALHO, J.C. Combined effects of elevated $\left[\mathrm{CO}_{2}\right]$ and high temperature on leaf mineral balance in Coffea spp. plants. Climatic Change, v.126, p.365-379, 2014. DOI: 10.1007/ s10584-014-1236-7.

MATOS, F.S.; WOLFGRAMM, R.; GONÇALVES, F.V.; CAVATTE, P.C.; VENTRELLA, M.C.; DAMATTA, F.M. Phenotypic plasticity in response to light in the coffee tree. Environmental and Experimental Botany, v.67, p.421-427, 2009. DOI: 10.1016/j.envexpbot.2009.06.018.

MORAIS, H.; MARUR, C.J.; CARAMORI, P.H.; RIBEIRO, A.M. de A.; GOMES, J.C. Características fisiológicas e de crescimento de cafeeiro sombreado com guandu e cultivado a pleno sol. Pesquisa Agropecuária Brasileira, v.38, p.1131-1137, 2003. DOI: 10.1590/ S0100-204X2003001000001.

MORAIS, H.; MEDRI, M.E.; MARUR, C.J.; CARAMORI, P.H.; RIBEIRO, A.M. de A.; GOMES, J.C. Modifications on leaf anatomy of Coffea arabica caused by shade of Pigeonpea (Cajanus cajan). Brazilian Archives of Biology and Technology, v.47, p.863-871, 2004. DOI: 10.1590/S1516-89132004000600005.

MORGAN, D.C.; SMITH, H. A systematic relationship between phytochrome-controlled development and species habitat, for plants grown in simulated natural irradiation. Planta, v.145, p.253-258, 1979. DOI: 10.1007/BF00454449.

PARTELLI, F.L.; VIEIRA, H.D.; DETMANN, E.; CAMPOSTRINI, E. Estimativa da área foliar do cafeeiro conilon a partir do comprimento da folha. Revista Ceres, v.53, p.204-210, 2006.

PARTELLI, F.L.; VIEIRA, H.D.; SILVA, M.G.; RAMALHO, J.C. Seasonal vegetative growth of different age branches of conilon coffee tree. Semina: Ciências Agrárias, v.31, p.619-626, 2010. DOI: $10.5433 / 1679-0359.2010 \mathrm{v} 31 \mathrm{n} 3 \mathrm{p} 619$.

PARTELLI, F.L.; MARRÉ, W.B.; FALQUETO, A.R.; VIEIRA, H.D.; CAVATTI, P.C. Seasonal vegetative growth in genotypes of Coffea canephora, as related to climatic factors. Journal of Agricultural Science, v.5, p.108-116, 2013.

PEZZOPANE, J.R.M.; CASTRO, F. da S.; PEZZOPANE, J.E.M.; BONOMO, R.; SARAIVA, G.S. Zoneamento de risco climático para a cultura do café Conilon no Estado do Espírito Santo. Revista Ciência Agronômica, v.41, p.341-348, 2010. DOI: 10.1590/ S1806-66902010000300004.

PEZZOPANE, J.R.M.; MARSETTI, M.M.S.; FERRARI, W.R.; PEZZOPANE, J.E.M. Alterações microclimáticas em cultivo 
de café Conilon arborizado com coqueiro-anão-verde. Revista Ciência Agronômica, v.42, p.865-871, 2011. DOI: 10.1590/ S1806-66902011000400007.

RAMALHO, J.C.; CAMPOS, P.S.; TEIXEIRA, M.; NUNES, M.A. Nitrogen dependent changes in antioxidant systems and in fatty acid composition of chloroplast membranes from Coffea arabica L. plants submitted to high irradiance. Plant Science, v.135, p.115-124, 1998. DOI: 10.1016/S0168-9452(98)00073-9.

RAMALHO, J.C.; DAMATTA, F.M.; RODRIGUES, A.P.; SCOTTI-CAMPOS, P.; PAIS, I.; BATISTA-SANTOS, P.; PARTELLI, F.L.; RIBEIRO, A.; LIDON, F.C.; LEITÃO, A.E. Cold impact and acclimation response of Coffea spp. plants. Theoretical and Experimental Plant Physiology, v.26, p.5-18, 2014. DOI: 10.1007/s40626-014-0001-7.

RAMALHO, J.C.; FORTUNATO, A.S.; GOULAO, L.F.; LIDON, F.C. Cold-induced changes in mineral content in Coffea spp. leaves - identification of descriptors for tolerance assessment. Biologia Plantarum, v.57, p.495-506, 2013. DOI: 10.1007/ s10535-013-0329-x.

RICCI, M. dos S.F.; COSTA, J.R.; PINTO, A.N.; SANTOS, V.L. da S. Cultivo orgânico de cultivares de café a pleno sol e sombreado. Pesquisa Agropecuária Brasileira, v.41, p.569-575, 2006. DOI: 10.1590/S0100-204X2006000400004.

RONQUIM, J.C.; PRADO, C.H.B.A.; NOVAES, P.; FAHL, J.I.; RONQUIM, C.C. Carbon gain in Coffea arabica during clear and cloudy days in the wet season. Experimental Agriculture, v.42, p.147-164, 2006. DOI: 10.1017/S0014479705003121.

SANTOS, H.G. dos; JACOMINE, P.K.T.; ANJOS, L.H.C. dos; OLIVEIRA, V.A. de; LUMBRERAS, J.F.; COELHO, M.R.; ALMEIDA, J.A. de; CUNHA, T.J.F.; OLIVEIRA, J.B. de. Sistema brasileiro de classificação de solos. 3.ed. rev. e ampl. Brasília: Embrapa, 2013. 353p.

SENEVIRATHNA, A.M.W.K.; STIRLING, C.M.; RODRIGO, V.H.L. Growth, photosynthetic performance and shade adaptation of rubber (Hevea brasiliensis) grown in natural shade. Tree Physiology, v.23, p.705-712, 2003. DOI: 10.1093/ treephys/23.10.705.

SILES, P.; HARMAND, J.-M.; VAAST, P. Effects of Inga densiflora on the microclimate of coffee (Coffea arabica L.) and overall biomass under optimal growing conditions in Costa Rica. Agroforestry Systems, v.78, p.269-286, 2010. DOI: 10.1007/ s10457-009-9241-y.

SILVA, F.C. da. Manual de análises químicas de solos, plantas e fertilizantes. 2.ed. Brasília: Embrapa Informação Tecnológica; Rio de Janeiro: Embrapa Solos, 2009. 627p.

SOUZA, H.N. de; GRAAFF, J. de; PULLEMAN, M.M. Strategies and economics of farming systems with coffee in the Atlantic Rainforest Biome. Agroforestry Systems, v.84, p.227-242, 2012. DOI: $10.1007 / \mathrm{s} 10457-011-9452-x$.

Received on July 7, 2014 and accepted on Octuber 23, 2014 